\section{(a) OPEN ACCESS}

\title{
Faecal microbiota transplantation (FMT) with dietary therapy for acute severe ulcerative colitis
}

\author{
Samuel Paul Costello (ㄷ, ${ }^{1,2}$ Alice Day, ${ }^{1,2}$ Chu K Yao, ${ }^{3}$ Robert Venning Bryant ${ }^{1,2}$
}

\begin{abstract}
'Department of
Gastroenterology, The Queen Elizabeth Hospital, Woodville South, South Australia, Australia 2Department of Medicine, The University of Adelaide Faculty of Health Sciences, Adelaide, South Australia, Australia ${ }^{3}$ Department of Medicine, Monash University, Clayton, Victoria, Australia
\end{abstract}

Correspondence to Dr Samuel Paul Costello sam.costello@sa.gov.au

Accepted 19 June 2020

Check for updates

(c) BMJ Publishing Group Limited 2020. Re-use permitted under CC BY-NC. No commercial re-use. See rights and permissions. Published by BMJ.

To cite: Costello SP, Day A, Yao CK, et al. BMJ Case Rep 2020;13:e233135. doi:10.1136/bcr-2019233135

\section{SUMMARY}

A 19-year-old man presented with acute severe ulcerative colitis. He was taking azathioprine (therapeutic metabolites) and sulphasalazine as well as infliximab with a therapeutic drug level. On day 3 of hydrocortisone therapy, he met day Oxford criteria with $>8$ bloody stools per day and was given faecal microbiota transplantation and subsequently commenced on dietary therapy combining several strategies - (1) increased intake of fermentable fibres, (2) reduced intake of overall and sulfur-containing protein and (3) restriction of sulfate and sulfite food additives. At week 8 assessment, he was in clinical and endoscopic remission and remained in clinical and endoscopic remission at 12 months.

\section{BACKGROUND}

Up to a quarter of patients with ulcerative colitis (UC) will develop acute severe colitis (ASC) during their disease course, a potentially life-threatening condition. ${ }^{1}$ Intravenous corticosteroids are the mainstay of therapy; however, approximately $30 \%-40 \%$ of patients progress to second-line (salvage) therapy with infliximab or ciclosporin. ${ }^{2}$ Despite salvage therapy, long-term colectomy rates remain high $(>50 \%$ at 3 years) and new therapeutic options are required. ${ }^{3}$

\section{CASE PRESENTATION}

A 19-year-old male carpenter presented to our hospital with ASC. He had a history of UC diagnosed 6 months prior, with poor disease control and four admissions to hospital with colitis requiring intravenous steroid therapy since diagnosis. At diagnosis, he had been commenced on azathioprine $150 \mathrm{mg}$ daily and sulphasalazine $1500 \mathrm{mg}$ two times per day. At his last presentation 10 weeks prior, he was also commenced on infliximab induction therapy with a partial response to therapy with a reduction from 10 bloody bowel motions per day to four non-bloody motions daily. $\mathrm{He}$ had completed three doses of induction therapy with infliximab $(5 \mathrm{mg} / \mathrm{kg})$ with the last dose 4 weeks prior to this presentation.

On admission, he reported eight bloody bowel motions per day with associated abdominal pain. On examination, he had mild generalised abdominal tenderness without guarding, pulse rate 114 beats/ min, temperature $37.6^{\circ} \mathrm{C}$ and blood pressure $135 / 78$ $\mathrm{mm} \mathrm{Hg}$. He was anaemic with a haemoglobin $(\mathrm{Hb})$ of $131 \mathrm{~g} / \mathrm{L}(135-175 \mathrm{~g} / \mathrm{L})$, his albumin was $40 \mathrm{~g} / \mathrm{dL}$ (34-48) and C-Reactive Protein was $4 \mathrm{mg} / \mathrm{L}$. Stool testing was negative for parasites, bacterial and viral pathogens and Clostridioides difficile toxin on nucleic acid amplification testing. He met Truelove and Witt's criteria for ASC ( $\geq 6$ bloody stools per day and two of pulse $>90$ beats $/ \mathrm{min}$, temperature $>37.5^{\circ} \mathrm{C}, \mathrm{Hb} \leq 100$ $\mathrm{g} / \mathrm{L}$ and ESR $>30 \mathrm{~mm} / \mathrm{hr}$ ). His thiopurine metabolites levels were therapeutic (6-thioguanine 400, 6-methylmercaptopurine 2907) and infliximab levels supratherapeutic (14.4 mg/L; range 3-7). Flexible sigmoidoscopy 3 days prior to admission had demonstrated moderately-severe colitis (figure 1 ) with histopathology and immunohistochemistry demonstrating no evidence of cytomegalovirus infection.

Despite receiving intravenous hydrocortisone 100 mg four times per day for 3 days, his stool frequency and bleeding failed to improve (nine stools per day) and he became more anaemic $\mathrm{Hb} 120 \mathrm{~g} / \mathrm{L}$ (135-175 $\mathrm{g} / \mathrm{L}$ ). Infliximab levels were $14.4 \mathrm{mg} / \mathrm{L}$ (trough range 3-7 mg/L). The patient met Oxford criteria for ASC ( $>8$ stools per day) and was offered and declined colectomy and was therefore offered donor faecal microbiota transplantation (FMT) with a dietary prescription as salvage therapy. The consent for FMT detailed the experimental nature of FMT in this setting and the greater evidence for surgical colectomy.

Severe confluent colitis (endoscopic Mayo -3) to the descending colon was noted at colonoscopy on day 4 of admission. FMT was delivered to the cecum and repeat FMT was given via enema on days 3 and 7 following colonoscopy as per the Adelaide protocol. ${ }^{4}$ The FMT had been sourced from a single anonymous stool donor 3 months prior at a stool bank. Fifty grams of donor stool had been processed under anaerobic conditions with $130 \mathrm{~mL}$ of normal saline and $20 \mathrm{~mL}$ of glycerol to produce a $200 \mathrm{~mL}$ suspension and then frozen at $-80^{\circ} \mathrm{C}$, prior to thawing on the morning of FMT delivery.

Dietary therapy was commenced immediately after initial FMT. The dietary prescription consisted of a whole diet approach that was (1) high in fermentable fibres, (2) reduced in overall and sulfur-containing protein, (3) restricted in sulfate and sulfite food additives and (4) was nutritionally replete. Dietary education with comprehensive meal plans and recipes were provided at weeks 0,4 and 8 . Azathioprine $150 \mathrm{mg}$ daily and infliximab $(5 \mathrm{mg} / \mathrm{kg}$ every eight weeks) therapy were continued during the 12 months follow-up period. Sulfasalazine was ceased by the patient 2 months after receiving FMT therapy.

\section{OUTCOME AND FOLLOW-UP}

The patient improved rapidly following the FMT and dietary therapy; stool frequency reduced to 2-3 motions per day without blood after 2 days. At weeks 4 and 8 , the patient was opening his bowels every second 


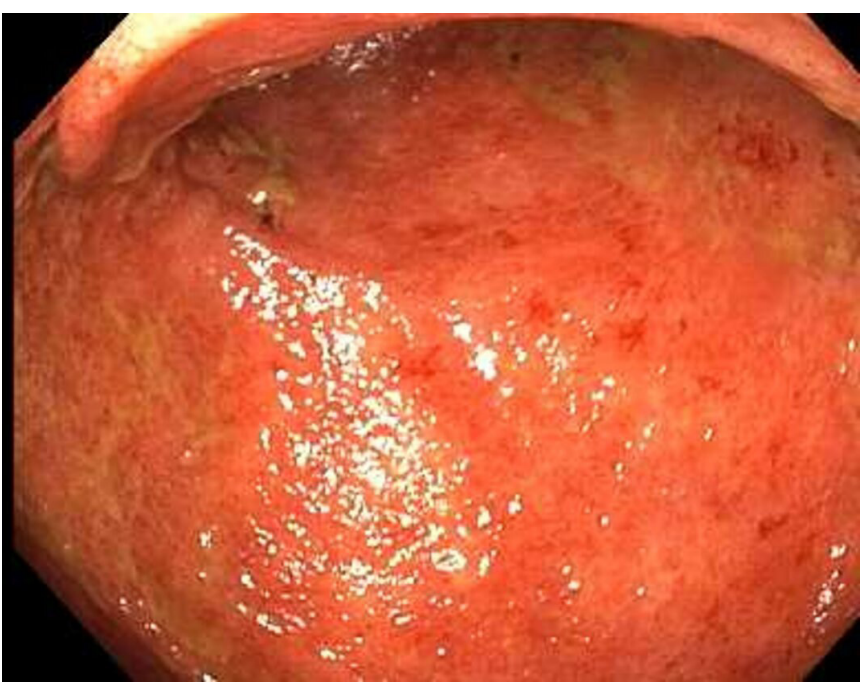

Figure 1 Sigmoid colon at week 0 (prior to faecal microbiota transplantation and dietary therapy).

day without blood. At week 4, flexible sigmoidoscopy demonstrated Mayo-1 colitis and at week 8 there was endoscopic remission (Mayo-0) (figure 2) and histological remission (absence of neutrophilic infiltrate). Dietary tolerability and compliance over the 8-week period was assessed to be excellent and he remained in clinical and endoscopic remission (Mayo-0) (figure 3) 12 months following FMT (faecal calprotectin $4 \mu \mathrm{g} / \mathrm{g}$ ).

\section{DISCUSSION}

Although the efficacy of FMT is established for remission induction of mild to moderate UC, ${ }^{56}$ FMT is not yet used routinely to treat UC in clinical practice and is not currently included in clinical practice guidelines. ${ }^{7}$ This is due to a number of factors, including the relatively recent emergence of induction of remission data, a lack of data demonstrating maintenance of remission with FMT, as well as legislative restriction, a lack of funding and poor availability of screened stool from stool banks in many jurisdictions. ${ }^{58}$

There have been reports of FMT inducing remission in patients with severe $\mathrm{UC}^{9-11}$; however, to our knowledge, this is the first case report of FMT as salvage therapy for ASC meeting Oxford criteria

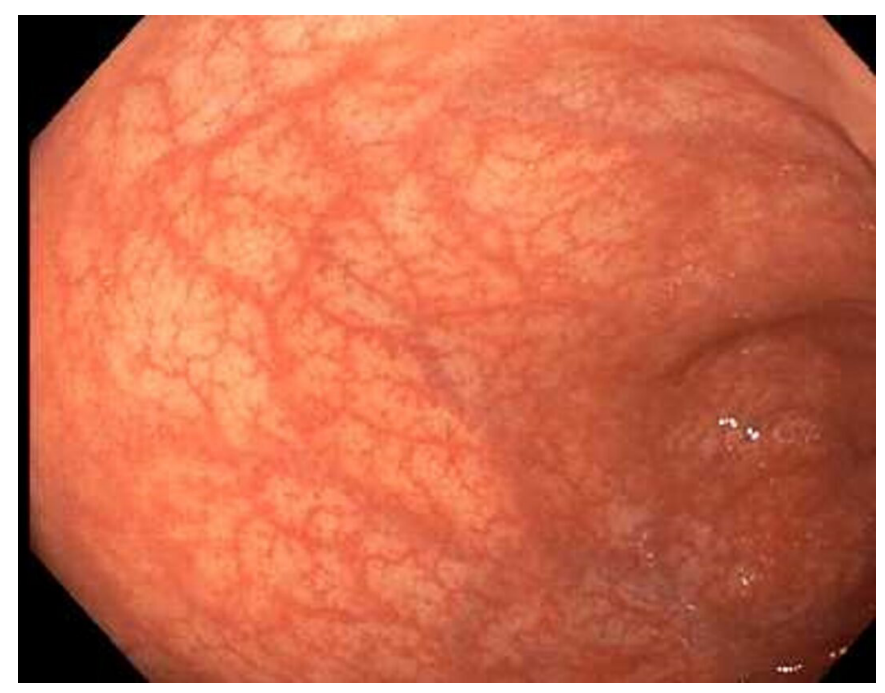

Figure 2 Sigmoid colon at week 8 post faecal microbiota transplantation and dietary therapy.

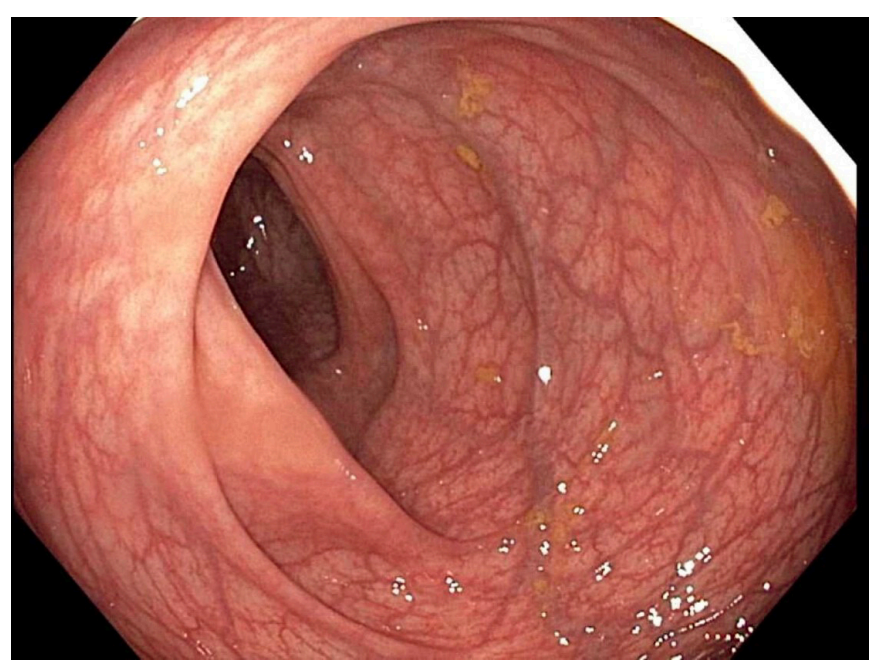

Figure 3 Sigmoid colon at 12 months post faecal microbiota transplantation and dietary therapy.

in a patient already receiving infliximab with therapeutic levels. This demonstrated the potential of FMT to alter the severe physiological changes present in ASC refractory to standard therapies. FMT likely acts via different mechanisms ${ }^{4}$ to current immunologically targeted therapies and thus may offer an adjunctive or alternative salvage therapy in the case of failure of hydrocortisone or infliximab. In this case, the infliximab dose was not increased because the infliximab level was high $(14.4 \mathrm{mg} / \mathrm{L})$ ciclosporin was not added as a therapy because there is a significant risk of infective complications with sequential or combination therapy. ${ }^{12} 13$

The prompt and durable efficacy of FMT observed in this case may have been augmented by a diet prescription. An excellent clinical and histological response of four patients with active UC to a low sulfur diet was first reported in $1998 .^{14}$ There is progressively more evidence emerging to indicate dietary therapy alone may influence disease activity in UC. ${ }^{15}$ There is also evidence that metabolites originating from activities of the colonic microbiota, both beneficial and toxic, can contribute significantly to epithelial defects documented in UC. Specifically, excessive exposure of the colonic epithelium to toxic hydrogen sulfide gas, a by-product of dietary protein and sulfur metabolism, produces biochemical lesions in the epithelium, mimicking those described in UC. ${ }^{16}$ On the other hand, there is also evidence that the fermentation of resistant starch and other prebiotic fibres by colonic bacteria is critical for enterocyte function and colonic health. ${ }^{17}$ The delivery of these nutrients to the colon is dictated by dietary intake and their metabolism is largely controlled by the colonic microbiota. Thus, it is likely that FMT and dietary therapy work synergistically. The mechanism by which FMT induces remission in UC is not known; however, in a recent randomised controlled trial of FMT for induction of remission of UC, lamina propria mononuclear cell populations correlated with disease severity (Mayo score) but were not correlated with donor FMT. ${ }^{4}$ This suggests that FMT may be inducing remission via a mechanism other than direct modulation of the mucosal lamina propria mononuclear cell populations. It is possible that alteration of the metabolic capacity of the microbiome plays a role in FMT-induced mucosal healing in UC. It is also possible that dietary therapy may augment this process by changing substrate availability and therefore, the types of metabolic activities. Further trials are warranted to explore whether FMT may have a place in the therapeutic armamentarium in ASC and whether diet has a role in augmenting and sustaining the efficacy of FMT. 


\section{Patient's perspective}

The faecal transplant and diet treatment was the last resort and it has paid off in a big way for me. Before the FMT and diet, I was on infliximab, azathioprine and sulfasalazine and I was in a bad way. Within two doses of the FMT, I felt a lot better and I have not had any problems since. It really sorted everything out for me. This was the turning factor for me. The FMT was not difficult or painful, I would do it a hundred times again for this result. The diet took more effort but I have been able to stick to the diet pretty well. I tried to follow the diet closely to help the FMT work.

\section{Learning points}

- Acute severe ulcerative colitis (UC) is assessed using Truelove and Witt's criteria and patients meeting these criteria should be commenced on intravenous hydrocortisone.

- Patients who do not respond to intravenous hydrocortisone by day 3 should be offered rescue therapy with either Inflixmab or ciclosporin and assessed for surgical colectomy in case of failure of medical therapy.

- There is evidence that faecal microbiota transplantation can induce remission in UC and further study is required before this therapy should be routinely offered to those patients failing infliximab or ciclosporin rescue therapy.

- There is emerging evidence that dietary therapy may influence UC disease course; however, more research is required.

\section{Twitter Alice Day @Alice_APD}

Acknowledgements We would like to acknowledge the work of Associate Professor WEW Roediger and Professor Peter Gibson whose work contributed to the formulation of the dietary therapy used in this case.

Contributors SPC managed patient's care and stool bank, conceived of the idea for co-therapy and wrote the manuscript. AD administered the diet therapy, coordinated patient samples and edited the manuscript. CKY developed the dietary plan and edited the manuscript. RVB managed the patient's care and stool bank and edited the manuscript.

Funding The authors have not declared a specific grant for this research from any funding agency in the public, commercial or not-for-profit sectors.

Competing interests SPC reports support from Janssen, Shire, Ferring, Microbiotica and Pfizer. RVB has recieved research support from AbbVie, Emerge Health, Ferring, Janssen, Shire, and Takeda.

Patient consent for publication Obtained.
Provenance and peer review Not commissioned; externally peer reviewed.

Open access This is an open access article distributed in accordance with the Creative Commons Attribution Non Commercial (CC BY-NC 4.0) license, which permits others to distribute, remix, adapt, build upon this work non-commercially, and license their derivative works on different terms, provided the original work is properly cited and the use is non-commercial. See: http://creativecommons.org/ licenses/by-nc/4.0/.

\section{ORCID iD}

Samuel Paul Costello http://orcid.org/0000-0002-2857-1812

\section{REFERENCES}

1 Bernstein CN, Ng SC, Lakatos PL, et al. A review of mortality and surgery in ulcerative colitis: milestones of the seriousness of the disease. Inflamm Bowel Dis 2013;19:2001-10.

2 Seah D, De Cruz P. Review article: the practical management of acute severe ulcerative colitis. Aliment Pharmacol Ther 2016;43:482-513.

3 Ordás I, Domènech $\mathrm{E}$, Mañosa $\mathrm{M}$, et al. Long-Term efficacy and safety of cyclosporine in a cohort of Steroid-Refractory acute severe ulcerative colitis patients from the ENEIDA registry (1989-2013): a nationwide multicenter study. Am J Gastroenterol 2017;112:1709-18.

4 Costello SP, Hughes PA, Waters 0 , et al. Effect of fecal microbiota transplantation on 8-Week remission in patients with ulcerative colitis: a randomized clinical trial. JAMA 2019;321:156-64.

5 Costello SP, Soo W, Bryant RV, et al. Systematic review with meta-analysis: faecal microbiota transplantation for the induction of remission for active ulcerative colitis. Aliment Pharmacol Ther 2017;46:213-24.

6 Haifer C, Kelly CR, Paramsothy S, et al. Australian consensus statements for the regulation, production and use of faecal microbiota transplantation in clinical practice. Gut 2020;69:801-10.

7 Harbord M, Eliakim R, Bettenworth D, et al. Third European evidence-based consensus on diagnosis and management of ulcerative colitis. Part 2: current management. J Crohns Colitis 2017;11:769-84.

8 Costello SP, Bryant RV. Faecal microbiota transplantation in Australia: bogged down in regulatory uncertainty. Intern Med J 2019;49:148-51.

9 Moayyedi P, Surette MG, Kim PT, et al. Fecal microbiota transplantation induces remission in patients with active ulcerative colitis in a randomized controlled trial. Gastroenterology 2015;149:102-9.

10 Karakan T, Ibis M, Cindoruk M, et al. Faecal microbiota transplantation as a rescue therapy for steroid-dependent and/or nonresponsive patients with ulcerative colitis: a pilot study. Journal of Crohn's and Colitis 2016;10:S425-6.

11 Uygun A, Ozturk K, Demirci H, et al. Fecal microbiota transplantation is a rescue treatment modality for refractory ulcerative colitis. Medicine 2017;96:e6479.

12 Leblanc S, Allez M, Seksik P, et al. Successive treatment with cyclosporine and infliximab in steroid-refractory ulcerative colitis. Am J Gastroenterol 2011;106:771-7.

13 Maser EA, Deconda D, Lichtiger S, et al. Cyclosporine and infliximab as rescue therapy for each other in patients with steroid-refractory ulcerative colitis. Clin Gastroenterol Hepatol 2008;6:1112-6.

14 Roediger WE. Decreased sulphur aminoacid intake in ulcerative colitis. Lancet 1998;351:1555.

15 Suskind DL, Wu B, Braly K, et al. Clinical remission and normalization of laboratory studies in a patient with ulcerative colitis and primary sclerosing cholangitis using dietary therapy. J Pediatr Gastroenterol Nutr 2018;67:e15-18.

16 Roediger WEW. Review article: nitric oxide from dysbiotic bacterial respiration of nitrate in the pathogenesis and as a target for therapy of ulcerative colitis. Aliment Pharmacol Ther 2008;27:531-41.

17 Roediger WE, Millard S. Colonocyte metabolism. Gut 1996;38:792-3.

Copyright 2020 BMJ Publishing Group. All rights reserved. For permission to reuse any of this content visit

https://www.bmj.com/company/products-services/rights-and-licensing/permissions/

BMJ Case Report Fellows may re-use this article for personal use and teaching without any further permission.

Become a Fellow of BMJ Case Reports today and you can:

- Submit as many cases as you like

- Enjoy fast sympathetic peer review and rapid publication of accepted articles

- Access all the published articles

- Re-use any of the published material for personal use and teaching without further permission

Customer Service

If you have any further queries about your subscription, please contact our customer services team on +44 (0) 2071111105 or via email at support@bmj.com.

Visit casereports.bmj.com for more articles like this and to become a Fellow 